\title{
Drought Risk Reduction Efforts in The Village of Krendowahono Gondangrejo Karanganyar Using Geolistric Surveys
}

\author{
Sorja Koesuma, Budi Legowo, Darsono, Iwan Yahya, Harjana
}

Universitas Sebelas Maret

sorja@staff.uns.ac.id

\section{Article History}

accepted 31/08/2020

approved 22/09/2020

published 28/10/2020

\begin{abstract}
Krendowahono, Gondangrejo, Karanganyar regency is located in the north of Surakarta city which is in 2019 the most affected area of drought. During August 2019 to November 2019, the village needs 2 to 5 water tanks dropping per day with a capacity of 5000 liters per tank. With such drought conditions, the villages government should provide clean water for their citizens. The method used for determining groundwater aquifers is the Geoelectric Method. This method works by injecting an electric current into the ground surface, then measuring the potential difference. Based on the obtained resistivity value, it can be interpreted at what depth there are groundwater aquifers. At the geoelectric survey location in Krendowahono village, it was found that the groundwater aquifer might be in layer 5 at a depth of 92.3 meters below, but the groundwater potential at this layer was not huge enough. Potential aquifers are likely to be from a depth of 92.3 meters to $110-120$ meters.
\end{abstract}

Keywords : Krendowahono Karanganyar, drought, aquifer, geoelectric method

\section{Abstrak}

Desa Krendowahono Kec. Gondangrejo Kab. Karanganyar terletak di utara Kota Surakarta yang pada tahun 2019 menjadi daerah paling parah mengalami kekeringan. Pada bulan Agustus - November 2019 setiap hari dilakukan dropping air sebanyak 2 sampai 5 tangki air dengan kapasitas 5000 liter tiap mobil tangki, untuk lima dusun di desa Krendowahono. Dengan kondisi kekeringan seperti itu, maka perlunya desa agar dapat mandiri menyediakan air bersih untuk warganya. Metode yang digunakan untuk penentuan akuifer air tanah adalah dengan Metode Geolistrik. Metode ini bekerja dengan menginjeksikan arus listrik kedalam permukaan tanah, kemudian mengukur beda potensialnya. Berdasarkan nilai resistivitas yang diperoleh dapat diinterpretasi pada kedalaman berapa terdapat akuifer air tanah. Pada lokasi survai geolistrik di Desa Krendowahono diperoleh hasil bahwa akuifer air tanah kemungkinan terdapat pada lapisan 5 yaitu pada kedalaman 92,3 meter ke bawah, namun potensi air tanah pada lapisan ini tidak terlalu banyak. Hal ini karena pola grafik pada lapisan ini makin kebawah makin naik nilai resistivitasnya, artinya makin tidak terdapat air. Potensi akuifer kemungkinan berada dari kedalaman 92,3 meter sampai dengan 110 - 120 meter.

Kata kunci : Krendowahono Karanganyar, kekeringan, akuifer, metode geolistrik 


\section{PENDAHULUAN}

Sesuai dengan amanat Undang-undang nomer 24 tahun 2007 tentang Penanggulangan Bencana bahwa Bencana adalah peristiwa atau rangkaian peristiwa yang mengancam dan mengganggu kehidupan dan penghidupan masyarakat yang disebabkan, baik oleh faktor alam dan/atau faktor non alam maupun faktor manusia sehingga mengakibatkan timbulnya korban jiwa manusia, kerusakan lingkungan, kerugian harta benda, dan dampak psikologis. Pada saat ini penanggulangan bencana baik alam maupun non alam, tidak dapat diserahkan sepenuhnya kepada pemerintah dalam hal ini Badan Penanggulangan Bencana Daerah (BPBD), namun ada kerjasama multipihak atau pentahelix yang meliputi unsur Pemerintah, Akademisi, Dunia Usaha, Media dan peran aktif Masyarakat.

Pada tahun 2019 merupakan tahun dengan kemarau yang sangat panjang di Indonesia sehingga menyebabkan bencana kekeringan. Sampai dengan Januari 2020 masih ada beberapa daerah (Maluku dan Kupang) yang masih sangat sedikit curah hujannya meskipun sudah memasuki musim penghujan. Namun rata-rata beberapa propinsi sudah masuk penghujan dan ada yang menyebabkan banjir dan banjir bandang. Kabupaten Karanganyar merupakan salah satu kabupaten yang berada di kaki Gunung Lawu di sisi barat. Daerah ini merupakan daerah surcharge (limpahan) air, dan mempunyai kandungan air yang cukup melimpah. Sebagian besar air yang bersumber dari Gunung Lawu ini digunakan untuk pemenuhan kebutuhan sehari-hari, industry/pabrik, pertanian maupun wisata.

Namun terdapat salah satu desa di Kab. Karanganyar yang kekurangan air pada saat musim kemarau 2019, yaitu Desa Krendowahono Kec. Gondangrejo Kab. Karanganyar. Desa ini terletak di paling barat-utara dari Kab. Karanganyar, sehingga sudah tidak berada di kaki Gunung Lawu. Wilayah desa ini berbatasan langsung dengan Kab. Sragen dan Kab. Grobongan. Pada musim kemarau tahun 2019 pada periode bulan Agustus sampai November, desa ini menerima dropping air sebanyak 2 sampai 5 tangki air (@5000 liter) untuk lima dusun di desa Krendowahono. Total jumlah tangki air selama periode tersebut adalah 268 tangki, atau lebih kurang 1.538.000 liter air. Air tangki tersebut merupakan bantuan dari pemerintah dan donasi dari lembaga usaha maupun lembaga swadaya masyarakat

Dengan adanya kejadian bencana kekeringan atau krisis air bersih diatas dan pentingnya peran Universitas Sebelas Maret (UNS) dalam penanggulangan dan pencegahan bencana kekeringan pada masa-masa yang akan datang, maka diperlukan satu studi untuk memprediksi apakah terdapat potensi air tanah dalam di Desa Krendowahono. Metode yang digunakan adalah Metode Geolistrik, yaitu salah satu metode geofisika yang digunakan untuk pendugaan pelapisan struktur geologi termasuk deteksi akuifer air tanah dalam. Terdapat dua konfigurasi dalam metode geolistrik, yaitu pengukuran secara horizontal (mapping) dengan konfigurasi elektroda Wenner-Schlumberger dan pengukuran secara vertikal (sounding) dengan konfigurasi elektroda Schlumberger. Harapannya hasil dari penelitian ini dapat digunakan pemerintah desa/kabupaten sebagai referensi lokasi pengeboran air. Sehingga pada musim kemarau yang akan datang, Desa Krendowahono tidak kekurangan air bersih. 


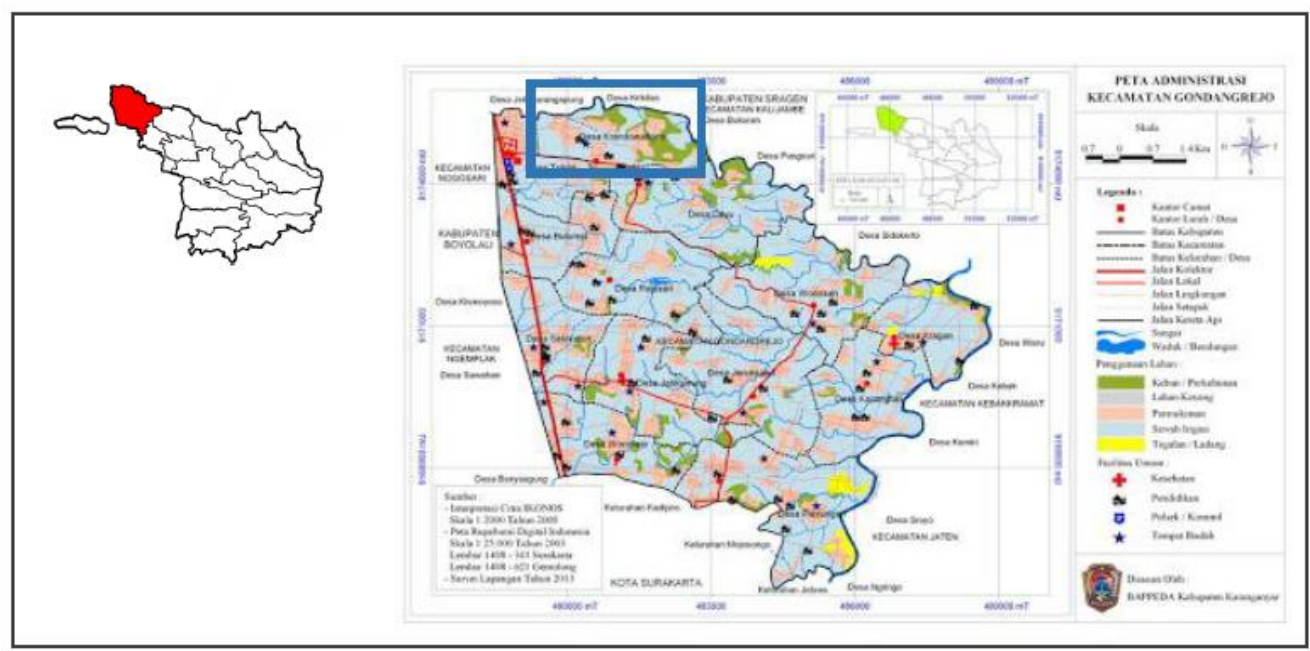

Gambar 1. Peta administrasi Kab Karanganyar (insert), warna merah adalah kecamatan Gondangrejo, sedangkan Desa Krendowahono dalam kotak warna biru (www.karanganyarkab.go.id, 2020)

\section{METODE}

Prinsip dasar metode geolistrik adalah mengukur nilai resistivitas dengan cara menginjeksikan arus dan kemudian mengukur nilai beda potensial yang ditimbulakan oleh injeksi arus tersebut. Dengan hukum Ohm setelah diketahui nilai beda potensial maka kemudian dihitung nilai resistivitasnya. Prinsip pengukuran geolistrik resistivitas dapat dilihat pada gambar 2 .

Pada pengukuran geolistrik digunakan 2 elektroda arus (C1 dan C2) dan 2 elektroda potensial (P1 dan P2). Beda potensial yang terukur merupakan beda potensial yang terukur pada titik elektroda P1 dan P2. Penentuan nilai resistivitas mengunakan persamaan 1. (Lowrie, 2007)

Gambar 2. metode geolistrik.

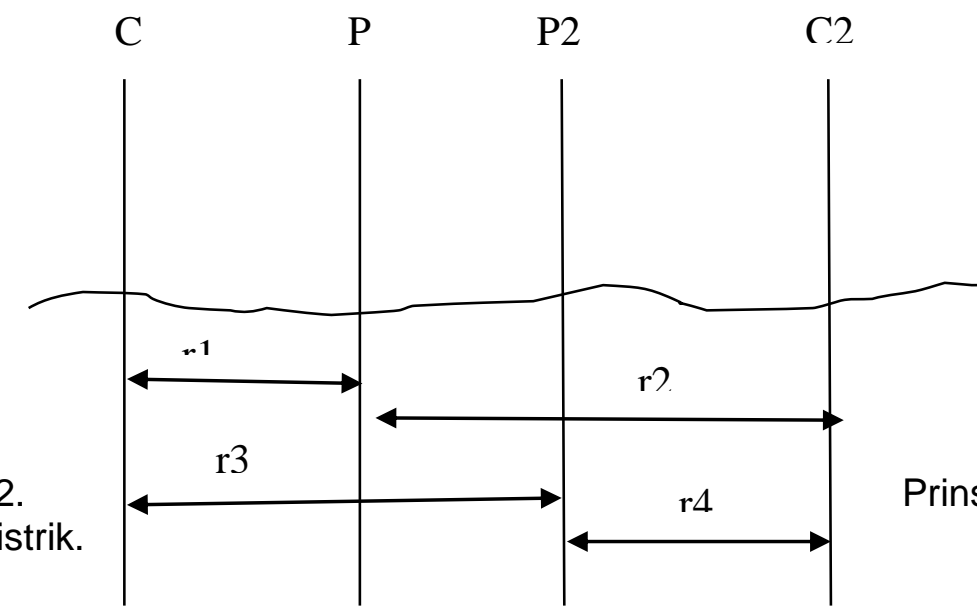

$$
\rho=K \frac{\Delta V}{I}
$$

Dengan 


$$
K=2 \pi\left[\frac{1}{r_{1}}-\frac{1}{r_{2}}-\frac{1}{r_{3}}+\frac{1}{r_{4}}\right]^{-1}
$$

$K$ merupakan faktor geometri yang sangat berpengaruh pada pengukuran geolistrik resistivitas. Nilai $K$ berbeda-beda tergantung dengan konfigurasi yang digunakan dalam pengukuran. Pengolahan data geolistrik mengunakan Metode Pencocokan Kurva (Curve Matching Method), yaitu mencocokan kurva hasil ukur geolistrik dengan kurva standar sehingga diperoleh nilai resistivitas dengan ralat kesalahan yang terkecil (Zohdy, 1983). Dengan mengunakan metode pencocokan kurva tersebut diperoleh nilai resistivitas, kedalaman dan ketebalan masing-masing lapisan. Kemudian nilai resistivitas masing-masing lapisan dicocokan dengan tabel referensi untuk mendapatkan jenis batuan dan kemungkinan terdapatnya akuifer atau tidak. Dalam menginterpretasi pelapisan batuan diperlukan juga peta geologi regional daerah survai, sebagai alat bantu untuk menentukan jenis batuan.

Tabel 1. Posisi koordinat geografis survai geolistrik

\begin{tabular}{lccc}
\hline \multicolumn{1}{c}{ Nama Lokasi } & S & E & Elevasi (m) \\
\hline $\begin{array}{l}\text { Desa Gondangrejo, Kec. } \\
\text { Mojogedang, Kab. Karanganyar }\end{array}$ & $7^{\circ} 27^{\prime} 59,50^{\prime \prime}$ & $110^{\circ} 50^{\prime} 31,46^{\prime \prime}$ & 105 \\
\hline
\end{tabular}

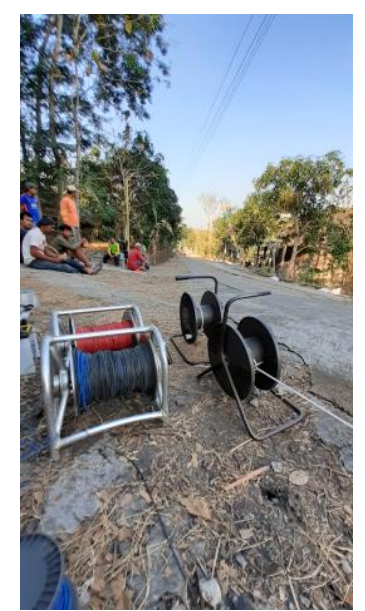

(a)

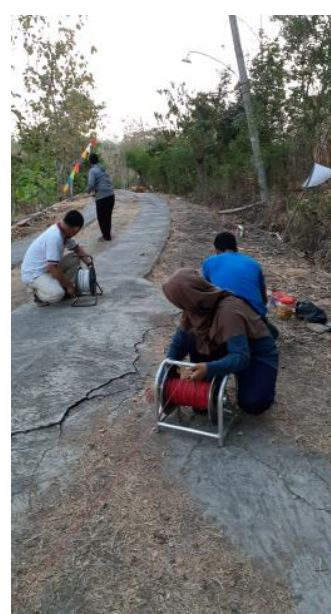

(b)

Gambar 3. Lokasi pengukuran survai Geolistrik (a) lintasan kearah timur, (b) lintasan arah barat.

\section{HASIL DAN PEMBAHASAN}

Pengolahan data Geolistrik mengunakan prinsip Curve Matching, atau Metode Pencocokan Kurva, yaitu mencocokkan antara data pengukuran dengan model sehingga diperoleh ralat yang paling kecil. Berikut ini adalah tahap - tahap dalam pengolahan data Geolistrik Resistivitas mengunakan software Progress.

1. Memasukkan data pengukuran yaitu nilai $A B / 2$ dan nilai resistivitas terukur.

2. Memasukkan prediksi pelapisan dan nilai resistivitas

3. Pemodelan balik (Inverse Modeling)

4. Looping nilai pemodelan untuk mendapatkan ralat terkecil

5. Diperoleh lapisan model struktur bawah permukaan berupa ketebalan dan nilai resistivitas masing-masing lapisan. 
Berdasarkan pengolahan data geolistrik mengunakan Metode Pencocokan Kurva diperoleh interpretasi sebagai berikut:

1. Lapisan 1 adalah weathering layer atau lapisan tanah lapuk dengan kedalaman 0 meter sampai 0,5 meter dengan nilai resistivitas $0,42 \Omega \mathrm{m}$.

2. Lapisan 2 adalah lapisan tuf halus dengan kedalaman 0,5 meter sampai 14,9 meter dengan resistivitas $3,15 \Omega \mathrm{m}$. Lapisan ini kemungkinan mengandung pasir dan terdapat kandungan air tanah dangkal atau permukaan.

3. Lapisan 3 adalah lapisan lempung pasiran dengan kedalaman 14,9 meter sampai 25,9 meter dengan resistivitas $0,10 \Omega \mathrm{m}$. Lapisan ini kemungkinan asin jika mengandung air, karena nilai resistivitasnya sangat rendah.

4. Lapisan 4 adalah lapisan lempung pasiran dengan kedalaman 25,9 meter sampai 92,3 meter dengan resistivitas $0,86 \Omega \mathrm{m}$. Lapisan ini serupa dengan lapisan 3 namun dengan nilai resistivitas yang sedikit lebih besar.

5. Lapisan 5 adalah lapisan tuf halus atau dapat juga berupa lapisan pasir dengan nilai resistivitas 2,5 $\Omega \mathrm{m}$ dengan kedalaman 92,3 meter ke bawah. Mulai pada lapisan ini kebawah kemungkinan terdapat akuifer air karena nilai resistivitas dan grafik yang diperoleh makin menaik dari nilai lapisan sebelumnya. 


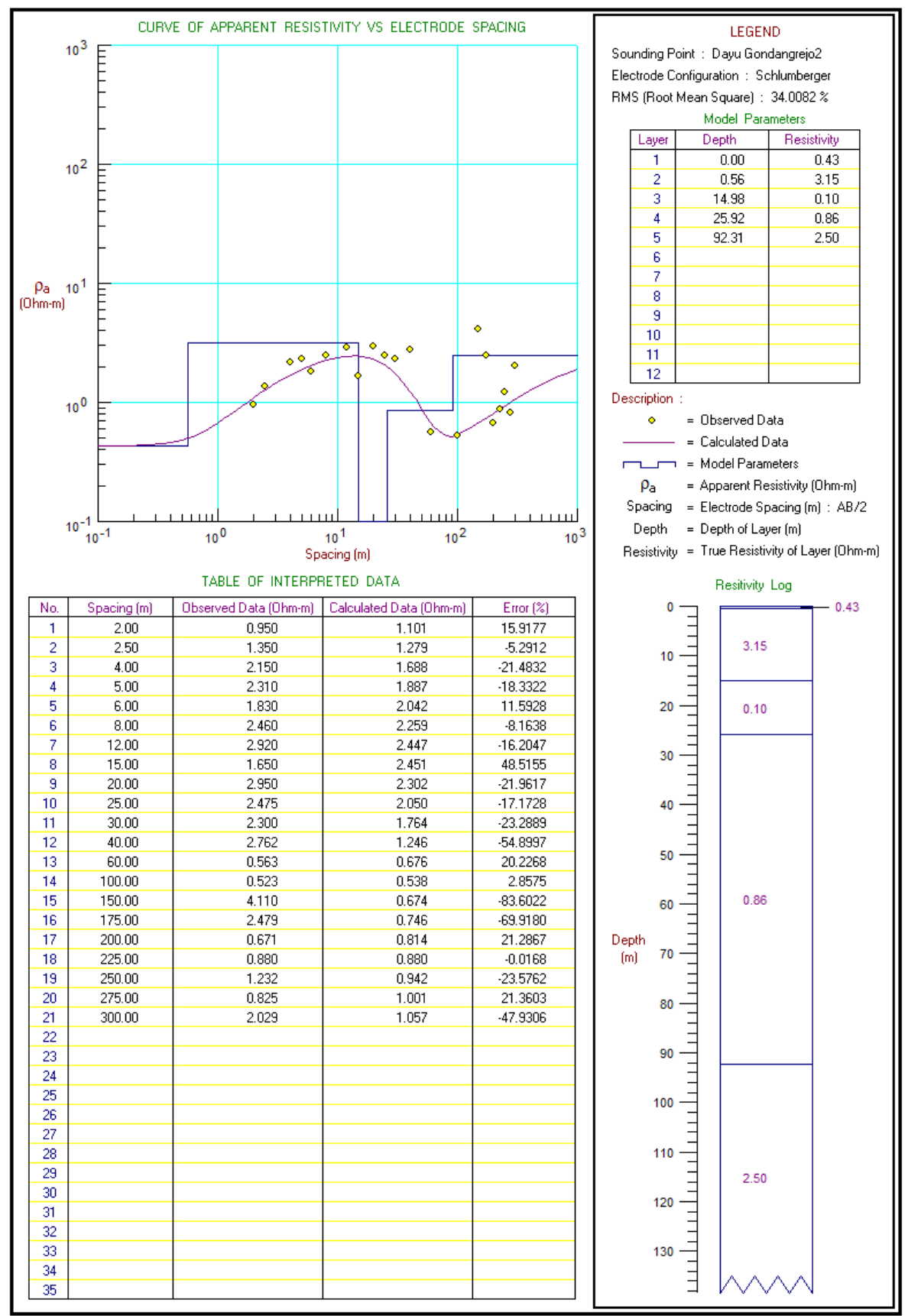

Gambar 4. Hasil interpretasi data geolistrik

\section{SIMPULAN}

Berdasarkan analisa diatas, keberadaan air tanah dalam kemungkinan terdapat pada lapisan 5 yaitu pada kedalaman 92,3 meter ke bawah dengan litologi batuan tuf. Pada kedalaman ini kemungkinan airnya sudah tidak berasa asin.

\section{DAFTAR PUSTAKA}

Badan Perencanaan dan Pembangunan Daerah Kabupaten Karanganyar. (2020). Peta Wilayah Administrasi Kecamatan Gondangrejo.

http://www.karanganyarkab.go.id/20110104/kecamatan-gondangrejo/ 
Lowrie, W. (2007). Fundamental of Geophysics. Cambridge. University Press.

Zohdy, A.A.R. (1983). Automatic Interpretation of Schlumberger Sounding Curves, Using Modified Dar Zarrouk Functions. Geological Survey Bulletin 1313-E. Washington: United States Government Printing Office. 